\title{
The housing crisis and London
}

\section{Michael Edwards}

Forthcoming 8 April 2016 in a Special Feature on London housing, edited by Paul Watt and Anna Minton in City Vol 20 No 2, 222-237, being launched at a conference in Stratford on $23^{\text {rd }}$ April 2016. Please do not quote or cite this version but cite the publisher's version which is at http://dx.doi.org/10.1080/13604813.2016.1145947.

\begin{abstract}
City has, from its inception, paid close attention to London, to the 'World-' or 'Global City' ideologies underwriting its concentration of wealth and of poverty and to challenges from among its citizens to the prevailing orthodoxy. This paper focuses on London's extreme experience of the housing crisis gripping the UK itself the European nation with the fastest long-term growth of average house prices and widest regional disparities, both driven by overblown financialisation and the privileging of rent as a means of wealth accumulation, often by dispossession. Londoners' experiences stem partly from four decades of neoliberal transformation, and partly from accelerated financialisation in the last two decades and are now being accelerated by the imposition of 'austerity' on low- and middle-income people. The social relationships of tenancy in social housing, private tenancy and mortgage-financed owner-occupation are, however, divisive and the paper ends by identifying what may be the beginning of a unified social movement, or at least a coalition, for change.
\end{abstract}

Keywords: London, rent, financialisation, dispossession, gentrification, displacement, wealth, income

Disclosure statement: this paper draws on a longer report commissioned and paid for by the Office of the Government Scientist as part of the Foresight Future of Cities project.

\section{Introduction}

This paper frames the housing situation in the UK - and London within itas a key element in the malaise, or perhaps crisis, of the whole society and economy. The falling share of the social product ending up as wages and salaries combines with growing income inequality among earners and growing wealth inequality to produce a widening gulf between those who can afford to house themselves in the market sectors and those who can't. In the three or four decades of neo-liberalism, the non-market housing sector (in the UK mainly council housing provided by local authorities but also $3^{\text {rd }}$ sector housing associations) has been eroded while the need for it has grown. Meanwhile the financialisation of British economic and social life has focused especially on housing and property markets with heavy 
flows of credit serving mainly to inflate prices in land and housing markets leading to acute affordability problems, overcrowding, homelessness and adverse health effects. London has been growing fast in population and economic activity but not proportionately in its housing capacity so it experiences extreme forms of these effects and is the site of some embryonic but fragmented resistance.

The initial framing of the problem as presented here is based on the arguments put forward in a recent report (Edwards 2015) commissioned by the Office of the Chief Scientist, an arms-length segment of the UK civil service, as part of Foresight: Future of Cities. This is a project with many contributors, the coordinators of which will be issuing a final report during 2016. The summary arguments here are only lightly referenced but the full report, a free download, has much greater detail. ${ }^{\mathrm{i}}$

\section{Housing in the UK}

The British housing system is dominated by private ownership of dwellings as financial assets, for many decades as owner-occupation but now also as private landlordism. The social relation of house purchase and asset-value appreciation is widely referred to as the 'housing ladder', but in reality it is closer to snakes and ladders since there are losers in the volatile price movements and in many parts of the UK households are stuck with homes 'worth' less than the debts they incurred to buy them. But for those who gamble successfully - and that means most buyers who maintain their mortgage payments in the southern parts of the country including London - the system is summed up in the report as more like an escalator than a ladder: a social process which converts the income of tenants and new buyers into capital appreciation for established owner-occupiers, landlords and financial institutions and profits for the landlords, professionals and construction interests which ride on the process.

It has been widely argued that the post-2007 economic crisis was partly triggered by a breakdown in the way investment in the built environment was taking place in many countries and the way it had become the focus of a fragile surge of rent-seeking speculation and financialisation (Martin 2011; Harvey 2012). Its origins are deeper, however, lying partly in the failure, since the 1970 s, of personal incomes to grow as fast as output or as fast as consumptionthe shortfall being partly made good by a boom of credit (Glyn 2006).

Market relations and financialisation were already very highly developed in the UK in the 1970s and became increasingly so in the 1980s, impelled via the Thatcher government's pioneering of utility privatisation, Urban Development Corporations, outsourcing and the disposal of public land assets alongside the relaxation of constraints on the financial sector, especially the de-regulation of mortgage markets (Muellbauer 2005). Later governments promoted the Private Finance Initiative (PFI), persevered with privatisation and enforced the treatment of publicly owned land and equipment as 'assets' to be managed on financial principles rather than as public services (Besussi 2016). 
The Bank of England $(2015,116)$ reports that the total assets of the UK financial sector had been about equal to one year's Gross Domestic Product (GDP) in 1958, grew to about 2 years' GDP by 1978 but expanded dramatically to reach 11 times GDP in 2013. This makes the British financial sector more than twice as dominant in UK economic life as it is in the USA, more so even than Switzerland, famously the country where money goes when it's ill.

Financialisation, however, is a set of fundamental transformations in recent capitalism, not merely the growth of the financial sector but also changes in the way in which non-financial firms think and behave. It is also a change in workers' and households' growing dependence on credit to secure use values and maintain an acceptable standard of living (Lapavitsas 2013). In the UK housing field we can see all of these strands at work. The financial sector and financial relationships have become ever more dominant, not just in the ways households manage their housing and saving strategies but in how local authorities and housing associations are now constrained to think of their land and social housing as 'assets', not use values, and to manage their rent policies and allocation of tenancies to meet the imperatives of securing finance. Financialisation has powerful cultural expressions too, as we see in popular TV series like Location, Location, Location, and creates strong imperatives on the work of built environment professionals whose products increasingly have to satisfy investors' criteria. The entire urban ensemble and the practices of participants become, as Louis Moreno (2014) puts it, both a product of financialised accumulation and a primary instrument enabling that accumulation to take place.

The post 1970s ascendancy of neoliberal policies of monetarism, privatisation and de-regulation in the OECD economies began a long shift characterised by broadly growing profitability alongside this financialisation. Over the subsequent years the proportion of the social product (roughly GDP) going to wages and salaries tended to be static or falling, in contrast to the previous decades in which the wage share of GDP had tended to rise (Stockhammer 2013). This changing picture is illustrated by Figures 1 and 2 below for various countries. A great deal of additional evidence on national and comparative change is to be found in the recent work of Piketty (2013: 222, 319-321) and the controversies (mostly about interpretations, rather than evidence) that it is generating. 


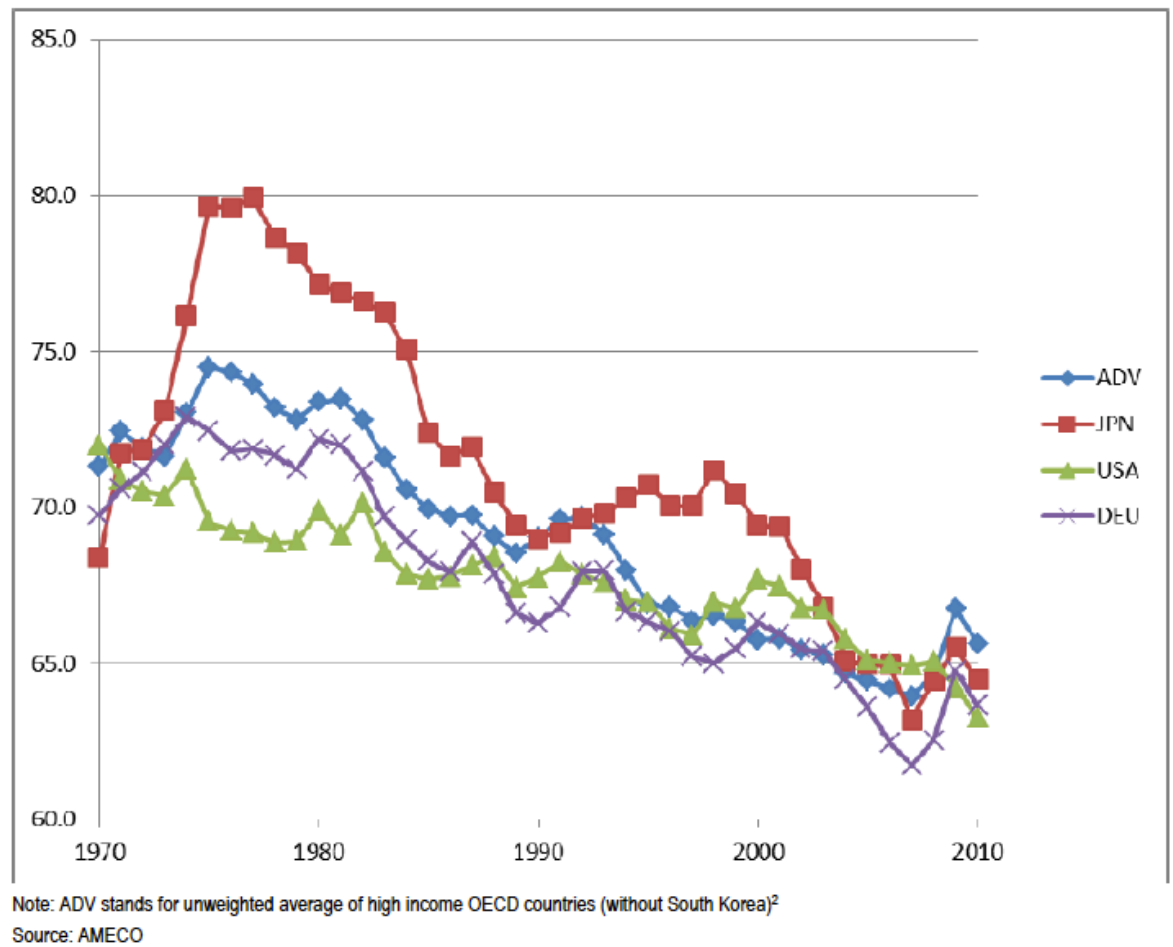

Figure I: Adjusted wage share of GDP, advanced countries, 1970-20 I0 Source: Stockhammer 2013 Fig I

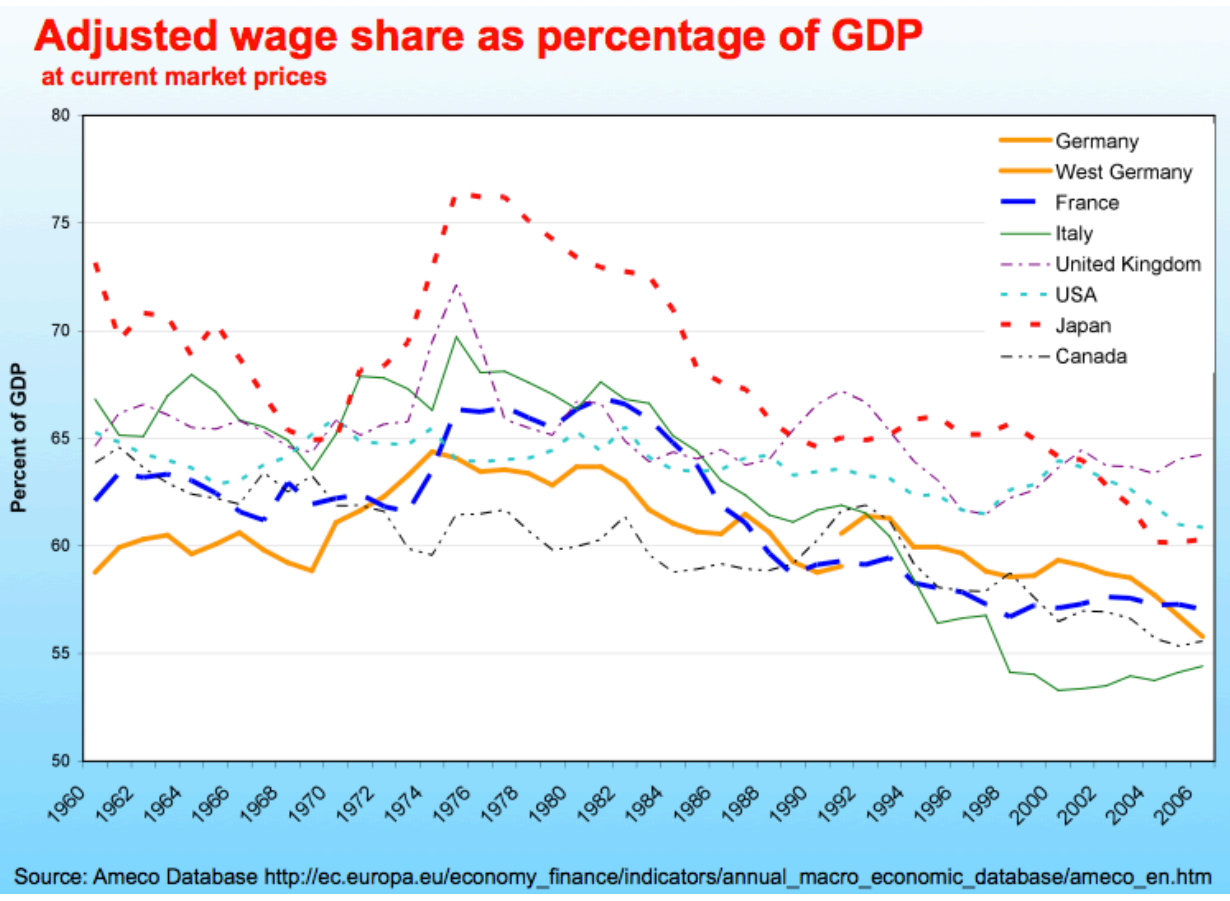

Figure 2: Adjusted wage share of GDP, various countries, 1960-2006 Source: Zeller (2009)

Thus a crucial element in the build-up to today's housing problems has been the relative weakening over four decades of the economic position of the working population: a shift in class struggle. While the changes in employment structures have weakened traditional working classes and their organisations, the tensions 
in society increasingly play out in urban life (Cox and Nilsen 2014; Merrifield 2014). Furthermore, income inequality has grown within the working population so that real incomes for many households have been flat or declining (Wilkinson and Pickett 2009; Piketty 2014; Atkinson 2015). It is this unequal spread of incomes which confronts the cost of housing in the market sector - the owner-occupier market and the private rental market- and in a period when the non-market sector has been shrinking.

Across the UK, and indeed across Europe and beyond, the failure of housing market systems to ensure that everyone is decently housed is recognised and the 'housing question' is back on the formal political agenda as well as provoking struggles by social movements. In addition to the crisis of affordability, criticisms are also made in the UK of floorspace, design and environmental standards, that new housing in the UK is often not where it is most needed, and that the construction industry is not fit for purpose. In the immediate aftermath of the breakdown of 2007 there was a wide consensus, even among mainstream commentators, that the financial and economic relationships surrounding housing which had emerged since the 1980s had also been major factors in bringing about -or at least triggering- the global financial crisis.

Within this broad narrative affecting most of the advanced countries, there were important differences in the lead-up to 2007/8. The 'credit crunch' was triggered by the collapse of the sub-prime mortgage market in the USA. This was the collapse of the securitised secondary market in low-grade mortgage loans which had been made on a large scale. The UK had a smaller scale of equivalent lending -famously most fragile in the Northern Rock collapse- but, as we have seen above, a uniquely large financial sector, which proved very expensive for the state to bail out when inter-bank lending stalled.

Societies with growing inequality produce worsening housing market experiences for poorer people and more pressure of need on their non-market sectors, partly because richer people can outbid poorer people, but partly also because, as people get richer, their consumption of space increases: in economic jargon the income elasticity of demand for space (indoors and outdoors) is high (Cheshire and Sheppard 1998). They tend to move to larger homes and/or acquire second homes. The distribution of housing space between income groups thus becomes more unequal, as Dorling (2013) has shown in detail.

This competition for housing space has been intensified by the state-sponsored and debt-financed expansion of individual owner-occupation of housing, reinforced by the near-cessation of non-market housing production (see Figure 3) and the erosion of inherited stocks of non-market housing through the Rightto-Buy (RTB) and other forms of privatization (see Watt and Minton, Introduction to this Special Feature). With home-ownership privileged in various ways in the tax system, UK households have been given strong incentives to maximise their ownership of housing as the core strategy of family saving and wealth accumulation and in periods of easy and/or cheap credit a majority have been able to do so in most areas (Scanlon and Kochan 2010; Robertson 2014). Households simply keen to house themselves securely, and without that wealth- 
accumulation motive, have unwittingly been part of the same process, enjoying the benefits of asset value growth in places and periods where it has taken place. The expansion and character of housing ownership has had an important political implication because so many UK households now have a personal interest in the maintenance and further growth of prices which, in turn, has made it very difficult for politicians even to contemplate strategies which would undermine this complex dynamic by bringing prices down. Those people's interest in maintaining house values and the strong tradition of amenity protection generate 'not in my back yard' (NIMBY) resistance to new development in many rural and urban areas. These anti-development pressures, operating through planning policies, combine with landowners' powers of withholding land from development to bring about strong growth of house prices in high-demand areas.

The UK's strongly embedded private landownership still peaks in a powerful residue of royal and aristocratic holdings, including ownership by institutions like ancient universities and livery companies - what Massey and Catalano (1978) called 'former landed property'. The most exhaustive study for Britain found that, "just 189,000 families own two-thirds of the UK's 60 million acres, of which nearly three-quarters is owned by the top 40,000" (Cahill 2001), and stressed the extreme difficulty in researching the topic because of the continuing lack of a complete land register. The transparency problem is in the process of being addressed in Scotland (LRRG 2014) but remains a major defect in the way in which land and property markets operate as Shelter and $\operatorname{KPMG}(2014,60)$ have stressed in their study of England and as Peter Hetherington dissects in his mainly rural Whose Land is Our Land? (2015).

Alongside and in addition to these two problems - of archaic ownerships and of secrecy surrounding who owns what - the UK experiences large scale ownership of land by financial institutions and developers. Rather little recent research is directed at the behaviour and significance of these owners and the ways in which their monopolistic or oligopolistic power works in the particular cities where they are active-or where they decline to act. Strong concerns about the probable spatial concentration effects of pension fund activity was expressed in the 1990s by Martin and Minns (1995) and there have been more studies of investor behaviour than of land-owner influence and of commercial rather than residential markets (see inter alia Henneberry 1995; Henneberry and Rowley 2000; Barras 2009).

The upshot of all this is that the stock of housing in the UK, and especially in England, has grown much more slowly than either the population or market demand, especially since building by local authorities was more-or-less halted in the 1980s (Figure 3). 


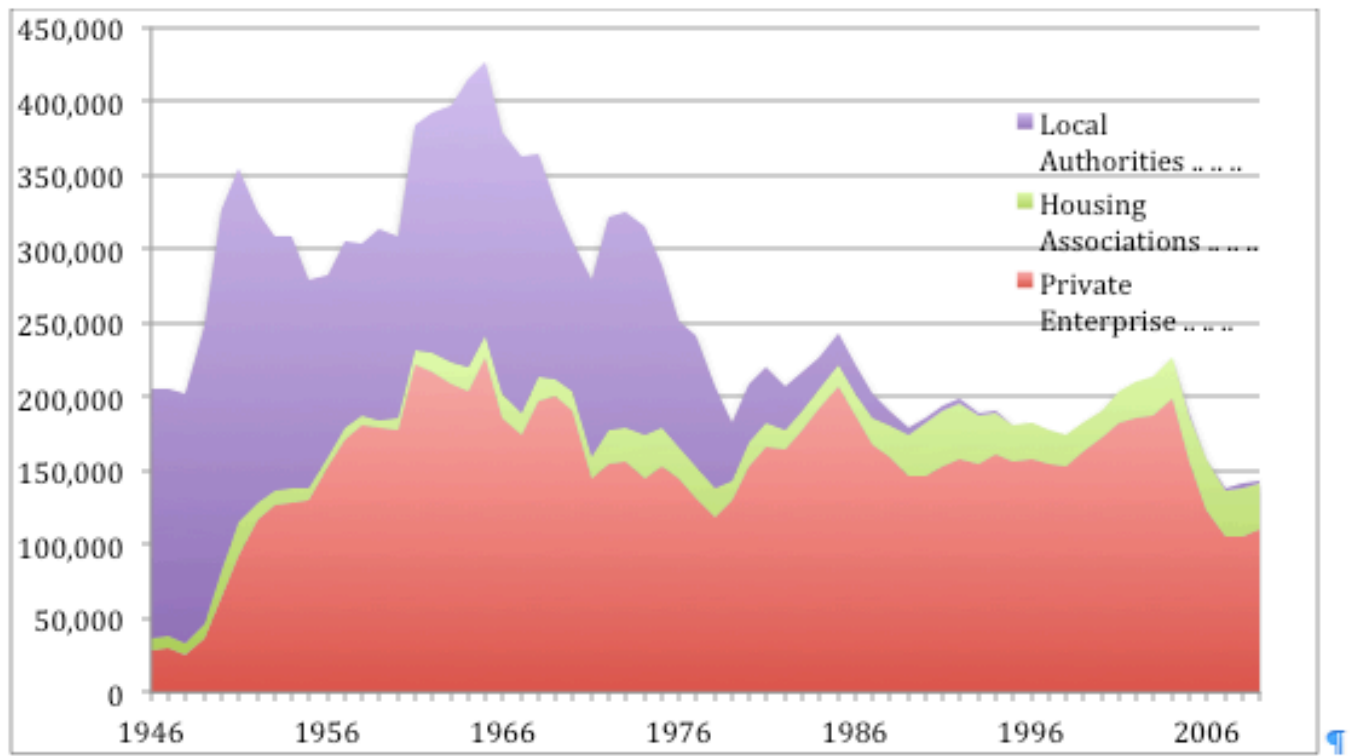

Figure 3. UK: Annual completions of dwellings by developer type 194620 I 2 after Barker (2004) Updated from DCLG Live Table 24 I

By 2007 the stock of housing and other real estate assets was nearly $90 \%$ of the market value of all tangible assets in the British economy, dwarfing the productive equipment of plants, machinery, vehicles and so on (see Figure 4). The growth of these property assets has, in recent decades, far exceeded the fixed capital formation in the building stock. In other words, the flows of money into land and property ownership have driven prices up to a much greater extent than they have brought forth a new supply of useful buildings. 


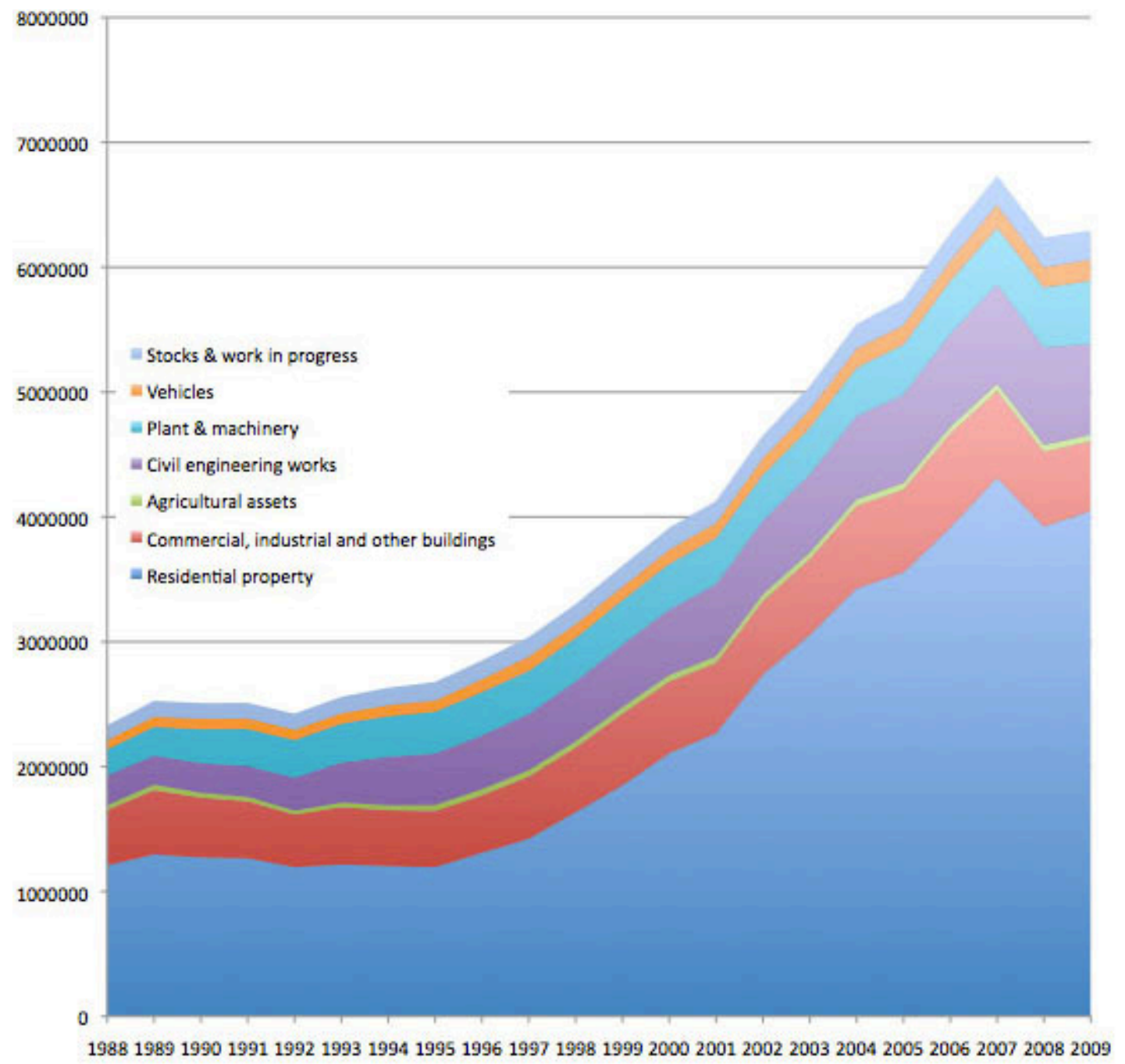

Figure 4. UK: Value of tangible assets, $€ m, 1988-2009$, Source: ONS Non-financial balance sheets (annual)

With prices rising and most real incomes static or falling, many households, especially in the southern half of the UK and in prospering cities have been unable to meet their expectations of becoming owner-occupiers; others are unable to access the social housing which had been (relatively) available to earlier generations in the post-war decades. Both of these groups found themselves diverted into an expanding private rented sector (PRS), the profitability of which attracted a lot of new investors, including Buy-to-Let landlords. This sector, which had, by the 1970s, become small and focused in cities, expanded in response to these demands and to the removal of rent controls and tenant security in subsequent years (see Watt and Minton, Introduction to this Special Feature). While this may be a tenure of genuine choice for some, it delivers some of the most squalid, insecure and overcrowded conditions we have seen for a hundred years and, in high-rent cities, is the source of mounting discontent and impoverishment. By 2012 the PRS sector is estimated at approaching a fifth of the dwelling stock: 18.5\% in England, 13.8\% in Wales, $12.8 \%$ in Scotland, 15.9\% in Northern Ireland and thus 17.7\% in the UK 
as a whole (Wilcox and Perry 2014). Owner-occupation in England and Wales peaked in about 2000 at $70 \%$ and has since been falling.

In sum, the market sector in housing fails to meet all society's needs and is now often described as "broken"; the term is used over 100 times in Shelter and KPMG (2014). The need for a non-market sector grows while it has actually been shrinking. The combined system fails to house the population well, amplifies inequality and is fragile.

The recent history, and the current state, of housing makes only limited sense at an aggregate UK scale, however, because needs, demands and outcomes are so strongly determined by the economic dynamics of individual cities and cityregions (and their related 'countrysides') and by the policy history of semiautonomous local planning and housing authorities and devolved administrations. These spatial variations are of mounting importance as uneven development among the parts of the UK unfolds (Martin et al. 2016) with very different experiences of rent and price changes, scarcities and other influences on welfare and economic activity.

Within cities too, spatial differentiation in housing prices and rents is often increasing, partly because commuting trips have been lengthening (Banister 2007) as cities grow: differential rents tend to increase as people pay more for better accessibility. In London the location of employment has been tending to centralise (Edwards et al. 2004; GLA Economics 2009; Smith 2011) while longdistance commuting has grown, contributing an upward effect on prices and rents in central areas and places with good transport to the centre. Price variations within cities also reflect differences in access to the best schools and environments (Cheshire and Sheppard 2004; Ahlfeld et al. 2012) and thus mediate who enjoys them.

Perhaps the simplest, but also the strongest, indication that the UK is an extreme case in the pumping of 'value' into its housing is that it has shown the strongest long-term growth of average house prices among all the OECD countries from 1970-2013 (Figure 5). 


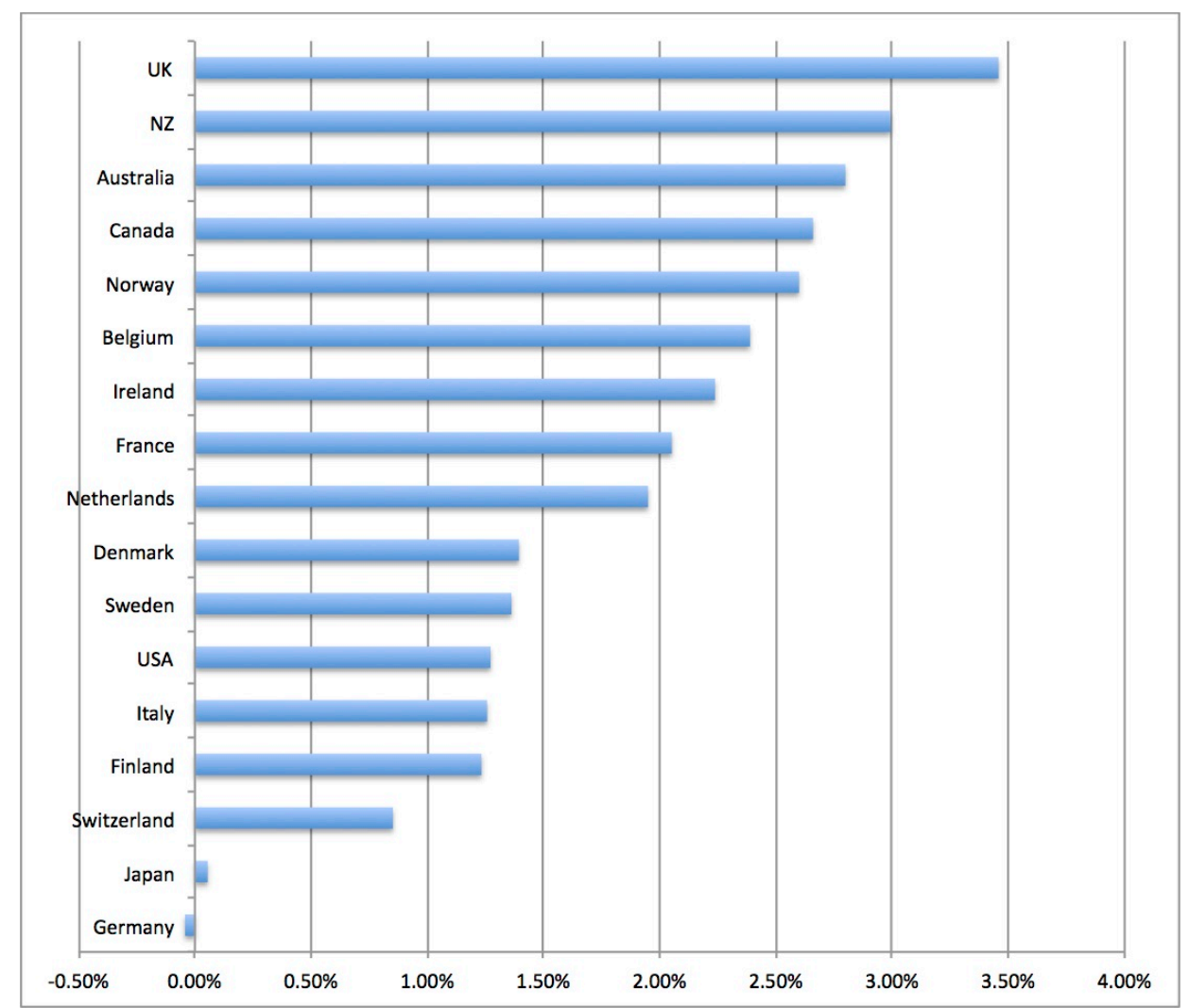

Figure 5: Annual average change in real house prices in OECD countries over the period 1970-2013. \% per annum compound, deflated by the consumer price index of each country. Source: OECD Housing Prices database 2014

The UK also has the most highly developed (in the sense of pervasive) investment property market in Europe. In other words, a very high proportion of UK real estate is owned by investors and rented out to occupiers, and this is so even though we have very little residential property owned in this way. Even with the recent resurgence of the private residential letting sector, only a small proportion of our housing stock is investment property in the sense that it is in the ownership of corporate/institutional owners.ii Thus, most of the UK's huge investment property stock is offices, retail shops and centres, industrial estates and the like (Figure 6). The biggest single element in this national stock of investment property is the central London office and retail market, reflecting the city's enormous 'weight' as real estate investment: a good bridge to the consideration of London housing problems which follows. 


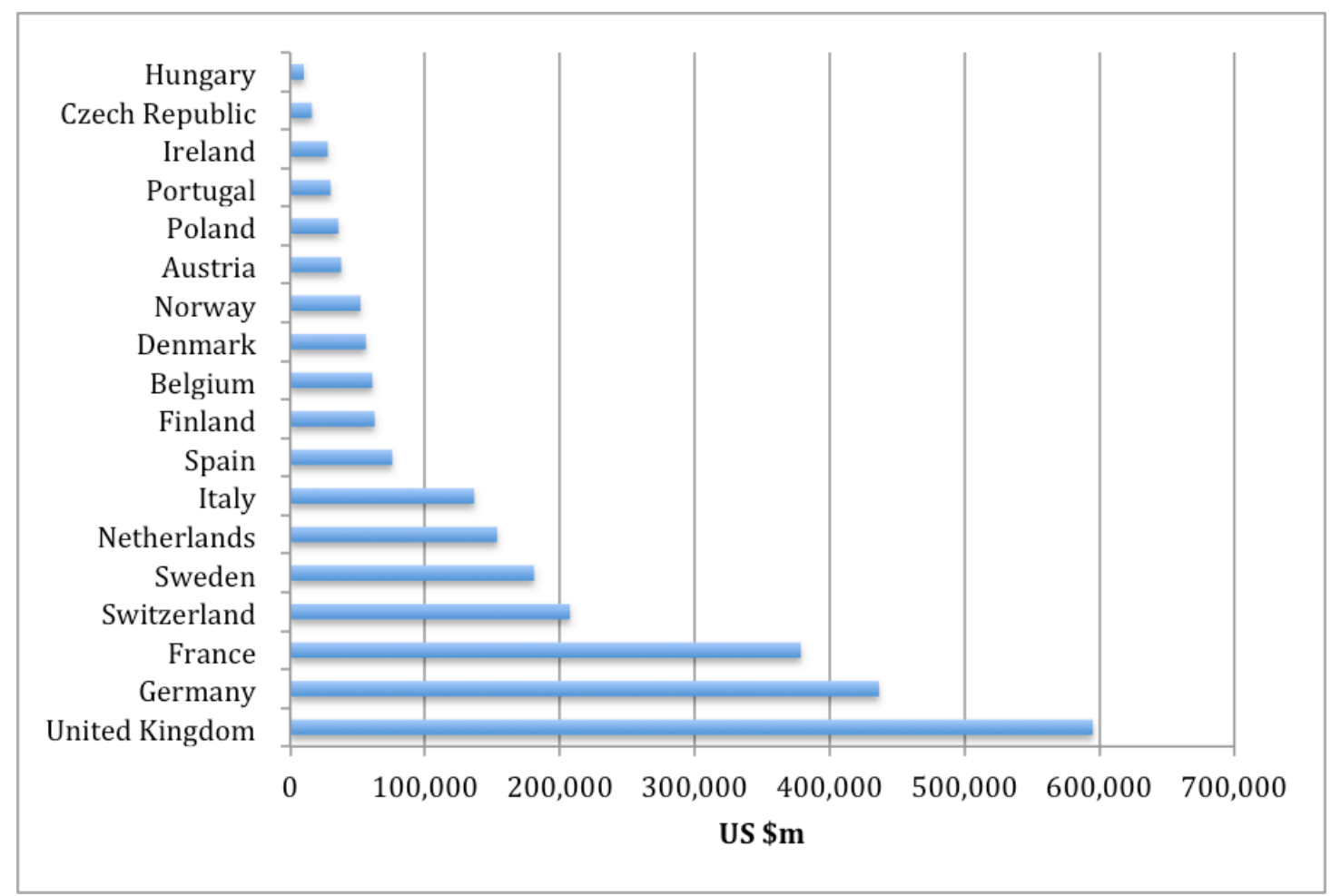

Figure 6: Size of Investment markets in property in European countries, 2013, \$m Source: IPD 2014 pers. comm.

\section{Housing in London}

London has long represented a strong co-location of national and international headquarter functions, financial and professional services (especially legal and accounting), cultural production and consumption, higher education, specialist medicine and national government. In this it resembles Paris but few other major cities. Notwithstanding this concentration of activity, London declined in population inside its administrative boundary until the mid-1980s (though with growth in surrounding counties outside its green belt). From that point onwards London has expanded both its population and its share of national output with its business and political leaderships developing and pursuing the city's development as 'Global City' or 'World City'. These concepts became dominant in the period 1985-2000 when London lacked a metropolitan government (Clark and Moonen 2012), and were rarely challenged (Edwards and Budd 1997), eventually becoming firmly embedded in the planning of London when it resumed in 2000 under Ken Livingstone as Mayor and Tony Blair as Prime Minister (Edwards 2002). iii Although Livingstone was in many ways a figure of the Labour left, he felt constrained to reach an accord with the financial and real estate interests of the City of London to have their support on a number of key policies: some major transport improvements and housing (Massey 2007). His approach to housing was to supplement the limited available grants from central government - which in any case he could not control - with contributions of land and money from private property developers to social housing under Section 106 of the Planning Act. From the outset he adopted policies to secure 
this objective in all his plans and the strategy had some success (Bowie 2010) even though his target levels of social housing provision were rarely met.

London grew strongly in the new millennium in terms of migration, domestic and international, and economic activity. Prices and rents in its housing markets were unruffled by the 'dot-com crash' and surged upwards until the credit crunch hit in 2007. Prices then fell, but only by about $15 \%$ and they had recovered by 2011 (Figure 7). Employment too, while faltering in 2008, has expanded faster than planners had expected, prompting the economic geographer Ian Gordon to wonder how London 'got away with'-being the main centre of banking and finance but not suffering a major downturn as a result. He concluded that it resulted from a "combination of public sector expansion (prior to the austerity programme), safeguarding of senior professional jobs, and a massive government bail-out of the major banks' wholesale operations" (Gordon 2011 §39). Growing employment, however, continued to exclude disproportionate numbers of low-skilled people, especially from some ethnic minorities, and to generate more and more in-work poverty (Wills et al. 2009). The low paid in London earn much the same as the low paid in other regions but face much higher housing costs. Thus real-terms median London household incomes recovered fast between pre- and post-crash (2007-8 to 2013-14) but after deducting housing costs they experienced the fastest fall of all British regions (Resolution Foundation 2016). Poverty and inequality in London remain severe (Trust for London 2013; Centre for London 2015) and its geography is changing.

Poverty continues to be produced across the city but, at least since the start of the millennium, central and inner areas of London have been the home to growing proportions of professional/managerial and higher-income people while outer areas -although in many cases remaining relatively rich on average - have been experiencing growing proportions of poor households and people in primary occupations. Neal Hudson mapped these changes for the interCensal period 2001-11, showing in detail how moves were bringing richer people into inner areas like Hackney and Tower Hamlets and poorer people into most outer suburban boroughs (Savills 2014).

These market-driven trends pre-date, but are reinforced by, changes to the social security regime. Since 2010 there have been changes to housing benefits (caps on local benefits related to local market rent levels) and caps on aggregate social security benefits which are rapidly making many of the areas in London where mixed-income communities had reproduced themselves for generations become unaffordable at a rate much faster than had already been caused by relatively stable market processes. The resulting exodus of Londoners from expensive to cheaper parts of London or beyond was predicted (Fenton 2011) and is under way (Imrie and Lees 2014; Hanna and Bosetti 2015).

In this context of surging population and employment, housing supply has failed to keep pace with the growth of housing need and of market demand, or to achieve even the planned outputs of housing, especially of social and other 'affordable' housing, called for in successive London Plans. 
London planning debates have been heavily preoccupied with the inadequacy of housing supply and affordability (Brown et al. 2015) and substantially undermined by the decision of the Coalition Government to abandon rational concepts of affordable housing based on maximum proportions of tenant incomes and to create a new term "affordable rent" defined as up to $80 \%$ of locally-prevailing market rents. This, combined with Mayor Johnson's decision to switch priorities away from housing those in greatest need to supporting total output and higher income people, has produced a very adverse policy context.

The growth of inequality in London has weakened the capacity of middle- and low-income groups to compete for housing space within the market stock while the size of the non-market - social housing - stock has shrunk through this failure of new production to keep pace with losses flowing from the RTB, from other privatisations and, recently, from the switching of tenancies in the sociallyowned stock from social rents to the much higher 'affordable' rents or even, in some cases, to market rents. These changes are quantified, so far as possible, in the evidence of the London Tenants Federation, TCPA and Just Space to the latest consultations on the London Plan (Just Space 2014a). At the time of writing it is clear that the new Conservative Government elected in 2015 is set upon the extinction of social housing at rents affordable by much of the population.

The provision of non-market housing in London, insofar as it happens, is costly because of the high prices commanded for land for private market development and has normally been possible only through a combination of government grant and agreements made between planning authorities and private developers under S106 to secure agreed proportions of units in new developments as social or 'affordable' housing (Bowie 2010). As explained above, Mayor Livingstone made as much use as he could of these mechanisms. Both of these mechanisms are weakening, however. Central government grants for social and 'affordable' rent housing have been reduced since 2010, and developers were able to argue that the fall in disposal prices for market housing after the post-2007 crisis threatened the 'viability' of projects containing significant social housing. Government ruled that 'viability' considerations should be paramount and even that pre-existing contracts could be re-negotiated downwards. Even now that disposal values have surpassed their pre-2007 levels, these changes remain in place so there has been a ratcheting-down of S106 provisions for social and 'affordable' housing (University of Reading et al. 2014; Colenutt et al. 2015). 


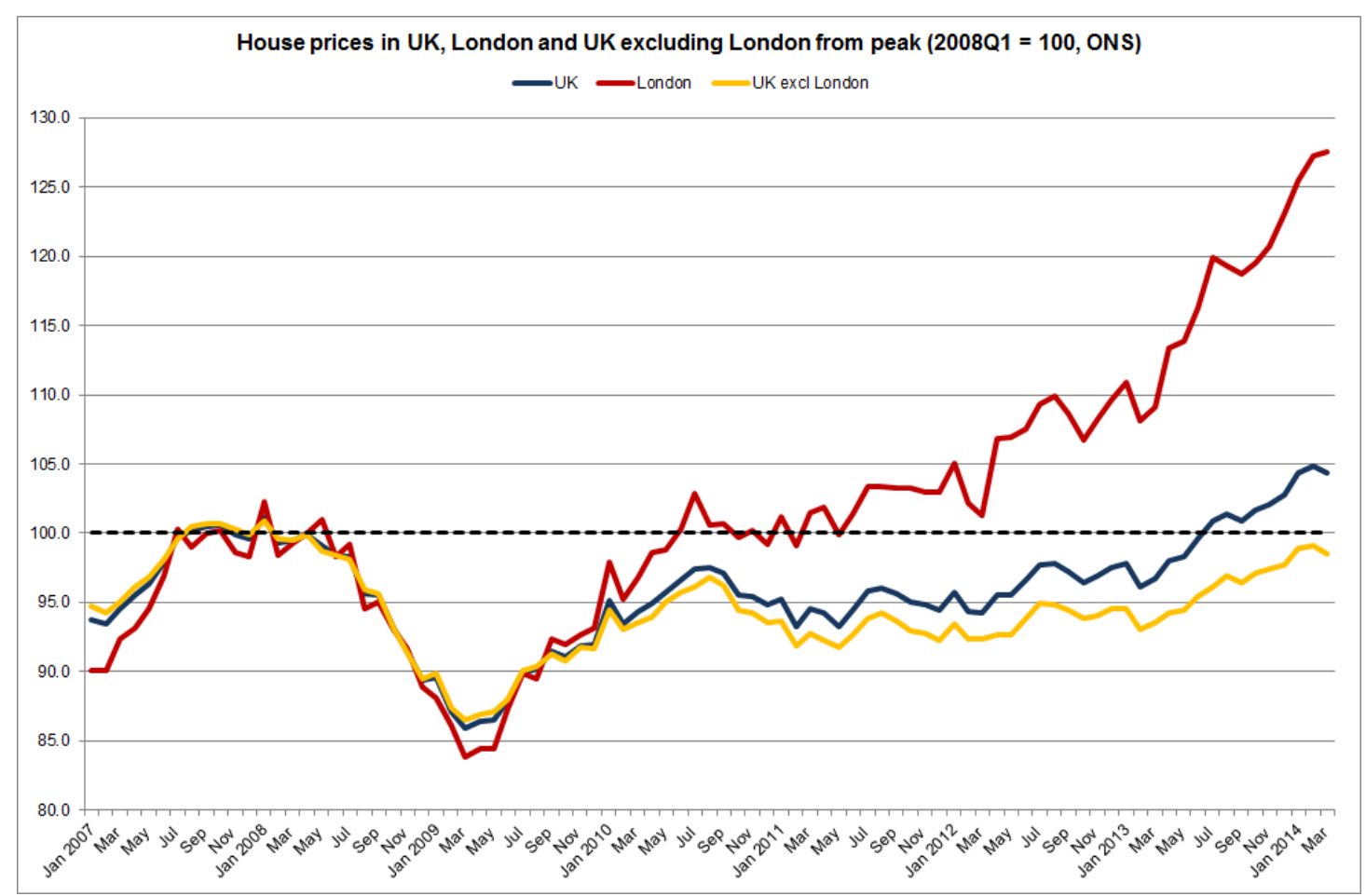

Figure 7. UK, London and the rest of the UK: house prices compared 200714

\section{Source: Joe Sarling using ONS data.}

Housing scarcity has also been affecting those with somewhat higher incomes who would previously have expected to enter owner-occupation, with large numbers of Londoners priced out of housing they can't afford. These people, along with those excluded from social housing, are thus constrained to rent in the growing PRS and there are many indicators of the resulting strains. For example we see the unprecedented formation of PRS tenants' campaigns, London Renters and some of the local groups in the Radical Housing Network. Nationally, the Priced Out campaign articulates the grievances of renters who are - or see themselves as - would-be owner-occupiers. The sector offers very poor security, short leases, unregulated rents and - in many cases - poor health and safety conditions.

The PRS is in fact an overlapping series of sub-markets, ranging from genuinely luxury houses and apartments to slum accommodation and everything in between. A distinctive niche has been the speculative development of rental housing for London's booming population of students, or at least for those from elite backgrounds around the world who can afford to pay very high rents per square metre for their rooms. This has been highly controversial both among lower-income students and for progressive local authorities which have sought to resist these developments because they take up sites which could have met local housing needs.

Government exhortations, following the Rogers Report (Urban Task Force 1999), that development should avoid greenfield sites and focus on previouslydeveloped ('brownfield') land reinforced the effect of the Green Belt in 
constraining the supply of sites and almost all house building in London has been on 'previously developed land' in the last decade. However, given the very extensive green space in London and the widespread existence of conservation areas, this has created very strong pressures for land use change from almost any other use to residential. Shelter and KPMG (2014: 35) cite industrial land prices in Croydon as being half of residential land prices and there is plentiful anecdotal and professional evidence of much higher ratios. Whereas many other British cities still have areas of disused or lightly used ex-industrial land, London has very little remaining and much of that has decontamination problems or needs costly infrastructure to bring it into use. Pressure on non-housing uses of space in London has become very intense indeed (Ferm and Jones 2015; Just Space 2015).

One of the most socially disruptive and controversial forms of this creation of 'brownfield' sites is the demolition of council-built housing estates which has increasingly been undertaken in the name of regeneration, often without adequate consultation, and involving disruption and some degree of dispersal of established communities (see inter alia Watt 2009, UCL Urban Laboratory 2013; Imrie and Lees 2014; Just Space 2014b; see Flynn, this Special Feature).

The market sector of London housing has also been meeting elements of demand which are, to varying degrees, additional to housing the city's settled population. These include investment purchases by UK and foreign residents and companies who then keep the flats empty or use them only occasionally. This category blurs into the second home/pied-a-terre kind of demand. There are grave problems in defining these categories and in measuring their extent. Controversy, and sometimes xenophobia, surround these issues but they probably are responsible for diverting a lot of sites which could otherwise be meeting the city's more ordinary demands and for contributing to rising prices, especially at the expensive end of the markets. (See Glucksberg in this Special Feature)

Finally, it needs to be stressed that London's housing pressures of course reach far beyond the boundaries of the GLA. Needs generated in London (especially central London where employment is concentrating) are perforce partly met in the surrounding villages, towns and cities, raising prices in those areas out of the reach of many who work there and occasioning the need for very heavy government investment in rail capacity. This dependence on the rest of the region, however, is entirely unplanned and estimates of prospective 'overspill' to other areas suggest magnitudes of 20,000 London worker households buying into the stock beyond Greater London annually (NLP 2014) which could affect 400,000 dwellings over the next two decades ${ }^{\text {iv }}$ (see also Bowie 2014; TCPA 2015).

It is also evident that, while the benefits of agglomeration through London's continuing 'economic' growth are held implicitly by mainstream policy communities (Mayor of London 2014; London First 2014) to be boundless, without these heavy state investments, especially in transport, the expected growth simply could not be sustained. We even hear now that some of the major financial employers in the City of London and Canary Wharf are returning to the 
19th century practice of providing direct housing for their workers since the city's market mechanisms can no longer do so. My tentative conclusion is that the national state invests in infrastructure, supported by the imperatives outlined in the Mayor's plans, while the benefits are harvested as additional rents accruing to owners of property.

\section{Conclusion}

On the one hand, London has an extremely 'high-value' built environment and its value has mushroomed in recent decades, generating massive profits and capital gains (rents); the consequence is the amplification of inequality while many Londoners are inadequately housed, space standards are low, value for money poor, funds for social and physical infrastructure and services can't be found and the environmental performance of the resulting settlement pattern is substandard. Furthermore the low- and middle-income communities and individuals who have coexisted with the rich for generations are being expelled painfully and violently. It is a dreadful paradox, a severe contradiction.

Put like this, however, it is clear that the problem could be solved. There is lots of money being spent on housing and more of it could go on what needed - good quality, well-designed, affordable housing with good services, environments and workplaces - with less being distributed as profits and capital gains/rents.

It is as though there were two kinds of tax in society: one paid to the state and local authorities for public services, the other an unofficial tax paid as rent to landlords, financial institutions, developers and established owner-occupiers. The city is indeed the wealth machine and poverty machine it was evidently becoming 20 years ago (Edwards 2002), but in an accelerated and violent form.

\section{Implications for urban theory}

Although the Foresight Future of Cities project is cast in terms of the fashionable cities discoursev, this framing questions its validity in two ways: irstly, through casting doubt on the unbounded net social benefits to be had from continued urban concentration. Secondly, through trying to demonstrate that the social relations of land and housing ownership are partly reflected in the relationships between cities and their attendant 'countrysides'. London can, for the moment, continue its growth but only through its interdependence with the rest of the nation (and indeed the world) in terms of migration, commuting and the flows of materials and commodities. ${ }^{\mathrm{vi}}$ Although this short paper has focused strongly on housing, it must be emphasised that one factor contributing to a 'housing crisis' is the fragmentation of scientific, social scientific and cultural disciplines (and of professions) which has made it so hard to bring all the relationships into focus simultaneously. 


\section{Implications for action}

City has, from its inception, paid close attention to London, to the 'World-' or 'Global City' ideologies underwriting its concentration of wealth and of poverty and to challenges from among its citizens to the prevailing orthodoxy (Wilson 2015, 585-6).

The main political parties, nationally and locally, have so far shared in the dominant triumphalist celebration of London's growth, differing only in the attention paid to social or 'affordable' housing. Blair, Brown and Livingstone did channel some public money into social housing production and did seek to leverage some social housing out of the profits made by private developers and land owners. The Labour Party, however, has always failed to halt the losses of inherited social housing through the RTB and through the 'regeneration' of estates in ways which decimated their social housing content (see Watt and Minton, Introduction to this Special Feature).

Undoubtedly a majority of London residents and workers are suffering severely from the housing crisis - uprooted, forced into frequent and disruptive moves between insecure private tenancies, squeezed between high rents and low wages (a chasm once bridged by various social security benefits, now being withdrawn), overcrowded or literally homeless. These oppressions should surely breed resistance. It has been slow to emerge, I suggest, mainly because the social relations involved in a financialised housing system are divisive. Owneroccupiers and would-be owner-occupiers are set against tenants; council tenants (among whom there is still a tradition of collective solidarity) and private tenants find difficulty in organising together while squatters tend to be demonised by many of those conventionally housed.

We do, though, now have a variety of social movements developing in London, some of which are discussed elsewhere in the Special Feature, including Focus E15, the Radical Housing Network, Priced Out, London Renters and Just Space (Lipietz 2014) in which I am working. It remains to be seen whether these fragments can coalesce as coherent social movements.

\section{References}

Ahlfeldt, G.M., N. Holman and N. Wendland. 2012. An assessment of the effects of conservation areas on value. London: LSE and English Heritage http://eprints.lse.ac.uk/44756

Atkinson, A. B. 2015. Inequality: What Can Be Done? Cambridge MA: Harvard University Press.

Banister, D. 2007. “Is Paradigm Shift too Difficult in UK Transport?” Journal of Urban Technology 14(2): 71-86. Online at: http://dx.doi.org/10.1080/10630730701531732 
Bank of England. 2015. "Oliver Burrows and Katie Low, Mapping the UK financial system”. BoE Quarterly Bulletin, Q2, 114-129.

Barker, K. 2004. Review of Housing Supply. Delivering Stability: Securing our Future Housing Needs. Final Report - Recommendations. London: HMSO.

Barras, R. 2009. Building Cycles: Growth and Instability. London: Wiley.

Besussi, E. 2016 (forthcoming). "Extracting value from the public city: urban strategies and the state-market mix in the disposal of municipal assets". In Urban Austerity: Impacts of the global financial crisis on cities in Europe, edited by S. Schipper and B. Schoenig. Berlin: Theater der Zeit.

Bowie, D. 2010. Politics, Planning and Homes in a World City. London: Routledge.

Bowie, D. 2014. "A balanced approach to London's growth". In Kaleidoscope City: reflections on planning and London, edited by J. Manns. London: Colliers International and the RTPI.

Brown, R., M. Edwards and R. Lee. 2015. "Just Space: Towards a just, sustainable London". In Sustainable London?, edited by R. Imrie and L. Lees. London: Routledge.

Cahill, K. 2001. Who owns Great Britain? Edinburgh: Cannongate.

Catterall, B., and M. Wilson. 2014. "Introducing and Resituating a Debate About 'Planetary Urbanisation." City virtual special issue. Accessed August 2015.

Centre for London (2015) Inside out: the new geography of wealth and poverty in London. London: Centre for London. http://centreforlondon.org/wpcontent/uploads/2015/12/CFLJ3887-Inside-out-inequality_12.125_WEB.pdf

Cheshire, P.C. and S. Sheppard. 1998. "Estimating the Demand for Housing, Land and Neighbourhood Characteristics". Oxford Bulletin of Economics and Statistics 60(3): 357382.

Cheshire, P. and S, Sheppard. 2004. "Capitalising the Value of Free Schools: The Impact of Supply Characteristics and Uncertainty". Economic Journal 114(499): F397-F424.

Clark, G. and T. Moonen. 2012. London 1991-2021: The Honor Chapman Report: THE BUILDING OF A WORLD CITY. London, Wiley Blackwell

Colenutt, B, A. Cochrane and M. Field, 2015. "The Rise and Rise of Viability Assessment". Town and Country Planning 84(10): 453-458

Cox, L. and A. G. Nilsen. 2014. We Make Our Own History: Marxism and Social Movements in the Twilight of Neoliberalism. London: Pluto Press

Dorling, D. 2013. All that is solid: The great housing disaster. London: Penguin. 
Edwards, M. 2002. "Wealth creation and poverty creation: global-local interactions in the economy of London". City 6(1): 25-42 DOI:

$10.1080 / 13604810220142826$

Edwards, M. 2015. Prospects for land, rent and housing in UK cities, Working Paper 18, Foresight Future of Cities Project, Government Office for Science, free download from https://www.gov.uk/government/collections/future-ofcities\#working-papers or from http://societycould.wordpress.com

Edwards, M. and L. Budd. 1997. "Confirming conforming conventions: the Four World Cities Study". City (7): 171-181.

Edwards, M., S. Maguire and M. Tewdwr-Jones. 2004. Intra-Urban Polycentric Development: Suburban Trajectories. London: ODPM.

Fenton, A. 2011. Housing Benefit reform and the spatial segregation of low-income households in London, 34, Cambridge: Department of Land Economy.

Ferm, J. and E. Jones. 2015. London's Industrial Land: Cause for Concern?, UCL https://justspacelondon.files.wordpress.com/2015/02/ferm-jones-londons-industrialland-working-paper-final1.pdf.

GLA Economics. 2009. Economic Evidence Base to support the public consultation drafts of the London Plan. London: GLA.

Glyn, A. 2006. Capitalism Unleashed: Finance, Globalization, and Welfare, Oxford: OUP.

Gordon, I. 2011. “London capital of boom and bust?” Observatoire de la Société Britannique: la Revue (11): 69-88.

Hanna, K. and Bosetti, 2015. Inside out London: the new geography of wealth and poverty in London. London: Centre for London (interim report; fuller results in 2016) http://centreforlondon.org/wp-content/uploads/2015/12/CFLJ3887Inside-out-inequality_12.125_WEB.pdf

Harvey, D. 2012. Rebel cities: from the right to the city to the urban revolution, New York: Verso.

Henneberry, J. 1995. “Developers, property cycles and local economic development: the case of Sheffield". Local Economy 10(2): 23-25.

Henneberry, J. and S. Rowley. 2000. Property market processes and development outcomes in cities and regions, Research Papers. London: RICS Foundation.

Hetherington, P. 2015. Whose land is our land? The use and abuse of Britain's forgotten acres. Bristol: Policy Press. 
Imrie, R. and L. Lees. 2014. Sustainable London? The future of a global city. Bristol: Policy Press.

Just Space. 2014a. Evidence submitted to the consultation on the Further Alterations of the London Plan http://justspace.org.uk/consultation-responses

Just Space. 2014b. Staying Put - an anti-gentrification handbook for estates, produced with Southwark Notes and the London Tenants Federation http://southwarknotes.wordpress.com/2014/06/13/staying-putan-anti-gentrification-handbook-for-council-estates-in-london

Just Space. 2015. London For All: A handbook for community and small business groups fighting to retain workspace for London's diverse economies, justspace.org.uk

Lapavitsas, C. 2013. Profiting without producing: how finance exploits us all. London: Verso.

Lipietz, B. 2014. Just Space: Building a community-based voice for London planning, City, 18, 2, 214-225 free download http://dx.doi.org/10.1080/13604813.2014.896654

London First and the London Enterprise Panel. 2014. London 2036: an agenda for jobs and growth, London.

LRRG [Land Reform Review Group]. 2014. The Land of Scotland and the Common Good, 263. Edinburgh: Scottish Government.

Martin, R. 2011. "The local geographies of the financial crisis: from the housing bubble to economic recession and beyond". Journal of Economic Geography 11(4): 587-618.

Martin, R. and R. Minns. 1995. "Undermining the financial basis of regions: the spatial structure and implications of the UK pension fund system". Regional Studies 29(2): 125-144.

Martin, R., A. Pike, P. Tyler and B. Gardiner. 2016. "Spatially Rebalancing the UK Economy: Towards a New Policy Model?" Regional Studies 50(2): 342-357. http://dx.doi.org/10.1080/00343404.2015.1118450

Massey, D. 2007. "The World we're in: interview with Ken Livingstone". Soundings 36

Massey, D. and A. Catalano. 1978. Capital and Land: landownership by capital in GB. London: Edward Arnold.

Mayor of London. 2014. London Infrastructure Plan 2050, GLA.

Merrifield, A. 2014. The New Urban Question London: Pluto Press. 
Moreno, L. 2014. "The urban process under financialised capitalism". City 18(3): 244268.

Muellbauer, J. 2005. “Property Taxation and the Economy after the Barker Review”. The Economic Journal 115(502 Conference Papers): CC99-117.

NLP. 2014. Nathaniel Lichfield and Partners, evidence to the consultation on Further Alterations to the London Plan on behalf of Gladman Developments http://www.london.gov.uk/sites/default/files/285GladmanDevelopmentsLtdRe sponse.pdf

Piketty, T. 2014. Capital in the Twenty-First Century. Cambridge MA: Belknap Press of Harvard UP.

Resolution Foundation. 2016. Five charts that London's mayoral candidates need to see on living standards, blog post by Conor D'Arcy, 7 January, http://www.resolutionfoundation.org/media/blog/five-charts-that-londonsmayoral-candidates-need-to-see-on-living-standards/

Robertson, M. 2014. Housing provision, finance and well-being in Europe, FESSUD Working Paper Series No. 14, http://fessud.eu/wpcontent/uploads/2013/04/Housing-provision-Finance-and-Well-Being-inEurope-Working-paper-14.pdf

Savills. 2014. The Gentrification of London, blog post. http://www.savills.co.uk/research_articles/186866/171784-0

Scanlon, K. and B. Kochan, eds. 2010. London: coping with austerity: review of housing, planning and public policy issues. London: LSE.

Shaw, K. 2015. "The intelligent woman's guide to the urban question". City, 19(6): 781800 http://dx.doi.org/10.1080/13604813.2015.1090182

Shelter and KPMG. 2014. Building the homes we need: a programme for the 2015 government. London: Shelter and KPMG.

http://www.shelter.org.uk/_data/assets/pdf_file/0019/802270/Building_the_h omes_we_need_-_a_programme_for_the_2015_government.pdf

Slater, T. 2016 (in press). "The Housing Crisis in Neoliberal Britain: Free Market Think Tanks and the Production of Ignorance". In The Handbook of Neoliberalism, edited by S. Springer, K. Birch and J. MacLeavy. London: Routledge.

Smith, D. 2011. Polycentricity and Sustainable Urban Form: An Intra-Urban Study of Accessibility, Employment and Travel Sustainability for the Strategic Planning of the London Region, PhD, UCL.

Stockhammer, E. 2013. Why have wage shares fallen? A panel analysis of the determinants of functional income distribution, Geneva, ILO. Conditions of work series \#35. 
TCPA. 2015. Town and Country Planning Association, articles on the Further Alterations to the London Plan 2014 by Duncan Bowie and Martin Simmons Town and Country Planning 84, 1.

Trust for London. 2013. London's Poverty Profile, 2013, London.

UCL Urban Laboratory. 2013. Urban Pamphleteer \#2: Regeneration Realities http://www.ucl.ac.uk/urbanlab/docs/UrbanPamphleteer2.pdf

University of Reading, Three Dragons, Hives Planning, David Lock Associates and DLA Piper LLP. 2014. Section 106 Planning Obligations in England, 2011-12: Report of study. London: DCLG

Urban Task Force. 1999. Towards an Urban Renaissance, London: Routledge.

Watt, P. 2009. "Housing stock transfers, regeneration and state-led gentrification in London". Urban Policy and Research 27(3): 229-242.

Wilcox, S and J. Perry. 2014. UK Housing Review: Chartered Institute of Housing.

Wilkinson, R and K. Pickett. 2009. The Spirit Level: Why More Equal Societies Almost Always Do Better. London: Allen Lane.

Wills, J., K. Datta, Y. Evans, J. Herbert, J. May and C. McIlwaine. 2009. Global Cities At Work: New Migrant Divisions of Labour. London: Pluto Press.

Wilson, M. 2015. 19.4, “City's holistic and cumulative project (1996-2016):(2)Towards millenium?”, City, 19 (4) 585-6

Zeller Christian. 2009. Die Gewalt der Rente: die Erschliessung natürlicher Ressourcen als neue Akkumulationsfelder. Zürich, SUISSE: Seismo.

Michael Edwards is... Email: m.edwards@ucl.ac.uk

\footnotetext{
i. When asked to write a report to government on housing prospects for UK cities I was initially reluctant. I'm not a 'housing expert' and doubted whether I should do work which could be construed as complicit with the neo-liberal trajectory of the Coalition Government of the day. In the end I agreed because for so long critical social scientists have belaboured governments for taking advice only from academics sympathetic to the neo-liberal project.

ii Mark Weedon at IPD — the independent Investment Property Databank - estimates that the institutionally-owned rental housing stock is only about 30-50,000 dwellings in 2013, compared with the total of about 5 million privately rented units (pers. com.).

iii The role of think tanks in elaborating this discourse is brilliantly analysed by Tom Slater (2016).

iv Similar concerns have been expressed by organisations as diverse as the TCPA and the HBF in evidence to the London Plan EiP 2014.
} 
v I am referring here to the rather triumphalist view of "cities" and their agglomeration economies as the engines of competitive economic and cultural life, best exemplified in the London context by the work of the LSE's Urban Age programme and the think tank Centre for Cities.

vi There is something to be said for elements of the Planetary Urbanisation approach in which the whole world is seen as being penetrated by urban relationships (Shaw, 2015, Catterall and Wilson 2014). 